gentry after 1572 and his descendents increased the estate through marriage and sheep farming. High Sheriff 1581. Bt 1627. (Finch, The Wealth of Five Northamptonshire Families, 4-24). First MP 1554.

1. Sir Justinian Isham $2 \mathrm{Bt}$ - Northamptonshire $1661-75$

2. Sir Justinian Isham $4 \mathrm{Bt}$ - Northampton 1685-87 1689-90 1694-98

3. Sir Justinian Isham $5 \mathrm{Bt}$ - Northamptonshire 1730-37

4. Sir Edmund Isham $6 \mathrm{Bt}$ - Northamptonshire $1737-72$

Seat: Lamport Hall, Northamptonshire (purch. 1560, built 1568, add. 1654-55, remod. 1732-42, add. 1819-21, charitable trust 1974)

Estates: Bateman 4230 (E) 7343. Perhaps worth $€ 1,600$ pa in the later $17^{\text {th }} \mathrm{c}$.

Title: Baronet 1627-

Notes: 2, 3, and 10 Bts and three others in ODNB.

JACKSON I IRELAND

Origins: The Rev. Richard Jackson of Kirby Lonsdale in Westmorland had a son Captain William Jackson, a tenant of the London Company in Coleraine, Ulster 1663. His son and grandson built up the estate. "Men of energy and resource." (Mullin, Coleraine in Bygone Centuries, 156)

1. William Jackson - \{Coleraine 1666

2. Samuel Jackson - \{Coleraine 1695-99\}

3. William Jackson - \{County Londonderry 1697-99\} (possible kinsman)

4. Thomas Jackson - \{Coleraine 1728-51\}

5. Richard Jackson - \{Coleraine 1751-89 Lisburn 1776 Randalstown 1783\}

6. George Jackson - \{Coleraine 1789-96 Randalstown 1797-1800\}

Seat: Jackson Hall (later The Manor House, Coleraine), Londonderry (acq. 1662, built 1680 , add. 1770 s, sold c. 1800 , demolished in $20^{\text {th }} \mathrm{c}$.)

Estates: Worth $£ 563$ pa in $1717, £ 1,003$ in 1736 pa, $£ 2,689$ pa in 1770 , and $£ 4,200$ pa in 1801.

Title: Baronet 1813-51

\title{
JACKSON II
}

Baron Allerton (1902- UK)

Origins: 1 Baron was the son of an inept tanner and leather merchant in Leeds. The former built up the business into a great enterprise. Mayor of Leeds 1895. 
1. William Jackson 1 Baron Allerton - Leeds 1880-85 N. Div. Leeds 1885-1902

2. Francis Jackson - Howdenshire Div. E. R. Yorkshire 1915-26

Seats: Loddington Hall, Leicestershire (built late $16^{\text {th }}$ c., add. late $17^{\text {th }}$ c., purch. 1934, trust 1992, for sale 2012); Allerton Hall, Yorkshire (demolished 1968)

Estates: 1 Baron purchased landed estates but lived at Allerton Hall in Leeds. 1 Baron left £250,000 in 1917.

Peers: 3 peers 1902-45

1 in Cabinet 1891-92

Notes: The tannery was closed in 1912 on the 1 Baron's retirement. None of his sons followed him into business. 1 Baron and one other in ODNB.

JAMES [Head]

\section{Baron Northbourne (1884- UK)}

Origins: The Heads began as Yorkshire yeomen who entered the gentry in the early $16^{\text {th }}$ century seated at Langley. High Sheriff 1698. In 1791 the Heads succeeded to the property of the Jameses of Denford via marriage 1778 and took the name James and were created Baronets. Father of the 1 Baron was Minister to the Netherlands. They inherited urban and industrial property in Gateshead and 4,300 acres from the Ellisons in the mid-19 ${ }^{\text {th }}$ century (see Carr Ellison).

1. John Head - Stockbridge $1685-87$

2. Walter James 1 Baron Northbourne - Hull 1837-47

3. Walter James 2 Baron Northbourne - Gateshead 1874-93

4. Cuthbert James - Bromley 1919-30

Seats: Betteshanger Park (House), Kent (built 1825, purch. 1850, remod. 1856 and 1886, sold 1933, now a school); Northbourne Court, Kent (built early $17^{\text {th }}$ c., fire 1750 , ruin, rebuilt $19^{\text {th }}$ C., purch. 1895 , still own); Langley Hall, Berkshire (built $17^{\text {th }}$ c., acq. by Heads c. 1650 , remod. $18^{\text {th }}$ c., transferred seat to Denford c. 1791, institutional use); Denford Court, Berkshire (acq. by Jameses 1778, passed by mar. to Heads, sold 1810); Evistones, Northumberland Estates: Bateman 6617 (E) 12949. Rubinstein - 1 Bt left £200,000 in probate in 1829. Title: Baronet 1791Peers: 4 peers 1884-1945

Notes: 1 Baron in ODNB. 


\section{JANSSEN}

Origins: Flemish Protestants settled in France came to England in 1683. The $1 \mathrm{Bt}$ was one of the most eminent merchants and financiers of his era, a founding Director of the Bank of England and the South Sea Company. Kt 1698. Bt. 1715.

1. Sir Theodore Janssen $1 \mathrm{Bt}-$ Yarmouth (IoW) 1717-21

2. Sir Abraham Janssen $2 \mathrm{Bt}$ - Dorchester 1720-22

3. Sir Stephen Janssen $4 \mathrm{Bt}$ - London 1747-54

Seat: Wimbledon House, Surrey (built c. 1585-88, remod. 1639-42, purch. and demolished 1717, sold 1723)

Estates: Worth $€ 200,000$ in 1721.

Title: Baronet 1715-77

Notes: 1 Bt lost heavily in the South Sea Bubble. 1 Bt in ODNB.

JEFFREYS [Price] ENGLAND \& WALES

Jeffreys (Jeffres)

Origins: A Brecon mercer before the Civil War and merchants in London in the American trade afterwards. Became very rich. Still active in business in the early $18^{\text {th }}$ century.

1. John Jeffreys - Breconshire 1661-62 Brecon 1679-81 1685-87

2. Sir Jeffrey Jeffreys - Brecon 1690-98 1701-09

3. John Jeffreys - Radnorshire 1692-98 Marlborough 1701-02 Breconshire 1702-05 Marlborough 1705-08

4. Edward Jeffreys - Marlborough 1702-05 Brecon 1709-13

5. John Jeffreys - Breconshire 1734-47 Dartmouth 1747-66

Seats: The Priory, Brecon, Breconshire (inher. by mar. 1678 from Price family, sold to a different branch of family 1689, they sold early $18^{\text {th }}$ c.); Pencoed Castle, near Newport in Gwent (built $13^{\text {th }}$ c., now a ruin, new house built $16^{\text {th }}$ c., purch. 1701, sold 1749)

Estates: Worth $€ 600$ pa in 1660 . Sir Jeffrey Jeffreys owned several thousand acres in Breconshire and was worth $€ 300,000$ c. 1699.

Notes: On the death of the last male Jeffreys the estates passed via an heiress to the 1 Earl Camden (see Pratt).

Notes: Two in ODNB. 
$\underline{\text { Price }}$ (Prise)

Origins: Claimed descent from a medieval Welsh king and a hero at Agincourt. Landowners since Tudor times. Did well out of the Dissolution. First MP 1547 for Breconshire. Two additional MPs 1571-1626 also for the county. Related to the Prices of Foxley (see Price III). The Price estates, including The Priory, passed to their cousins by marriage the Jeffreys family in 1689.

1. Sir Herbert Price $1 \mathrm{Bt}-$ Brecon 1640-43 1661-78

2. Thomas Price - Herefordshire $1661-79$

3. John Price - Herefordshire 1708-13

Seats: The Priory, Brecon, Breconshire (purch. c. 1540s, passed to Jeffreys 1678); Wistaston Court, Herefordshire (acq. $17^{\text {th }}$ c., sold early $18^{\text {th }}$ c., fire c. 1910)

Estates: Worth $€ 135$ pa in 1555 and $£ 300$ pa in the 1640 s.

Title: Baronet 1657-89 (Cromwellian)

Notes: Sold much land in the 1680 s and met final financial ruin in the early $18^{\text {th }}$ century. Related to Price III (see). One in ODNB.

\section{JENISON}

\section{Jenison}

Origins: An old Newcastle merchant family that entered the gentry through profits of office. First MP 1571 for Newcastle-on-Tyne. An additional MP 1601.

1. Ralph Jenison - Northumberland 1724-41 Newport (IoW) 1749-58

Seat: Walworth Castle, Durham (medieval, acq. 1579 , rebuilt later $16^{\text {th }}$ c., remod. 1740 s, sold c. 1759 , now hotel)

Notes: Some Jenisons remained Roman Catholic. In the later $18^{\text {th }} \mathrm{c}$. one moved to Germany, where he was a diplomat and made a Count. Four in ODNB.

\section{Jenison}

Origins: Cadet of the Newcastle family ( $16^{\text {th }}$ century). Were merchants in Nottingham from the 1580s; rose to gentry status c. 1660. High Sheriff 1684.

1. Sir Matthew Jenison - Newark 1701-05

Notes: Estates passed to a cousin, Elizabeth Bradford, in 1734. 
JENKINSON [Foljambe, Medley, Shuckburgh, Thornhaugh]

Earl of Liverpool (1796-1851 GB; 1905- UK)

Origins: Merchants in Bristol and agents for the Muscovy Company in the $16^{\text {th }}$ century. Granted arms 1568. Knighted by James I. Purchased land in Oxfordshire and Gloucestershire before the Civil War. Gentry by the 1620s. First MP 1654.

1. Sir Robert Jenkinson $2 \mathrm{Bt}$ - Oxfordshire 1689-1710

2. Sir Robert Jenkinson $3 \mathrm{Bt}$ - Oxfordshire 1710-17

3. Sir Robert Bankes Jenkinson $4 \mathrm{Bt}$ - Oxfordshire 1717-27

4. Charles Jenkinson 1 Earl of Liverpool - Cockermouth 1761-66 Appleby 1767-72 Harwich 1772-74 Hastings 1774-80 Saltash 1780-86

5. John Jenkinson - Corfe Castle 1768-80

6. Robert Jenkinson 2 Earl of Liverpool - Rye 1790-1803

7. Sir Charles Jenkinson $10 \mathrm{Bt}$ - Dover 1806-18

8. Charles Jenkinson 3 Earl of Liverpool - Sandwich 1807-12 Bridgnorth 1812-18 East Grinstead 1818-28

9. Sir George Jenkinson $11 \mathrm{Bt}-\mathrm{N}$. Wiltshire 1868-80

10. Cecil Foljambe 1 Earl of Liverpool - N. Nottinghamshire 1880-85 Mansfield Div. Nottinghamshire 1885-92

Seats: Hawkesbury, Gloucestershire (medieval, purch. 1621, demolished 1770s,); Eastwood Park, Gloucestershire (old house, purch. 1688, rebuilt 1820 and c. 1865, sold 1916); Hartsholme Hall, Lincolnshire (built 1862, purch. 1909, sold 1939, demolished 1951); Walcot, Oxfordshire (built $16^{\text {th }}$ c., acq. early $17^{\text {th }}$ c., remod. early $17^{\text {th }}$ c., sold 1759); Coombe Wood (Coombe House), Surrey (owned early $19^{\text {th }}$ c., institutional use); Pitchford Hall, Shropshire (purch. by Ottleys 1473, built c. 1549, passed by mar. to Jenkinsons $18^{\text {th }}$ c., passed by mar. to Cotes $19^{\text {th }}$ c.); Buxted Park, Sussex (built 1722, ad. 1810, inher. by mar. from Shuckburghs 1814, passed out of family by mar. 1871, hotel) Estates: Bateman 3624 (E) 5517. Rubinstein - 1 Earl left £200,000 probate 1809 and the 2 Earl £120,000 in 1828.

Titles: Baron Hawkesbury 1786-1851 GB; Baron Hawkesbury 1893- UK; Baronet 1661Peers: 6 peers 1786-1808 1803-51 1893-1945

2 in Cabinet 1778-82 1786-1804 1801-27

$1 \mathrm{KG} 19^{\text {th }}$

Notes: 1, 2, and 3 Earls of $1^{\text {st }} \mathrm{cr}$. and three others in ODNB.

Foljambe

Origins: The Foljambes claimed descent from a companion of the Conqueror. Owned Tideswell, Derbyshire from the $11^{\text {th }}$ century. (Roskell, Clark, and Rawcliffe, The House 
of Commons, III, 98) Baliffs of the Peak in the medieval period. Expanded estates at the Dissolution. First MP 1297 for Derbyshire. Five further MPs 1338-1626, three of them for the county. One of a cadet line married the daughter and heiress of the last Earl of Liverpool (d. 1851), and the title was revived for this family in 1905.

1. Frances Foljambe - Yorkshire 1784 Higham Ferrers 1801-07

2. Francis Savile Foljambe - East Retford 1857-85

Seats: Aldwarke Hall, Yorkshire (acq. and built early $17^{\text {th }}$ c., rebuilt c. 1720 , family departed, pulled down c. 1880/99, new house); Osberton Hall, Nottinghamshire (acq. from Thornhaughs by mar. 1774, rebuilt c. 1798, add. 1830 and 1840s, add. 1880s, sold post 1986)

Estates: Bateman 14498 (E) 20140.12,000 acres in the 1980s.

Title: Baronet 1622-40

Notes: The Foljambes acquired Aldwarke and the Earl of Southampton's estates by marriage to an heiress. That family elected many pre-1660 MPs. Aldwarke was engulfed by industrial growth in the second half of the $19^{\text {th }} \mathrm{c}$. and abandoned by the family.

\section{Thornhaugh}

Origins: Wealthy country gentry seated at Fenton since the reign of Henry VI. First MP 1604. Another MP 1640. Mary Thornhaugh, heiress of John Thornhaugh and Arabella, heiress of Sir George Savile 8 Bt of Rufford Abbey, married Francis Foljambe of Aldwarke.

1. John Thornhaugh - East Retford 1689-1702 Nottinghamshire 1704-10

2. John Thornhaugh - Nottinghamshire 1747-74

Seats: Osberton, Nottinghamshire (acq. 1682, passed to Foljambes by mar. later $18^{\text {th }}$ c.); Shireoakes Hall, Nottinghamshire (purch. by Hewetts mid-16 $6^{\text {th }}$ c., built 1612-17, remod. 1719-26, acq. by inher. 1726, fire 1811, sold 1812); Fenton Hall, Nottinghamshire (acq. $15^{\text {th }}$ c., passed out of family by mar. 1787)

Notes: John Thornhaugh of Osberton inherited the estates of his godfather Sir Thomas Hewett of Shireoaks, Nottinghamshire in 1726. Male line extinct 1787.

\section{$\underline{\text { Shuckburgh }}$}

Origins: Settled at Shuckburgh since the beginning of the $13^{\text {th }}$ century. Sheep farmers in $16^{\text {th }}$ century. High Sheriff 1568. Kt 1642. First MP 1640 for Warwickshire. The 3 Earl of Liverpool married Julia Shuckburgh-Evelyn, sole heiress of Sir George Shuckburgh- 
Evelyn 6 Bt. Their daughter married George Savile Foljambe of Aldwarke, whose son was created Earl of Liverpool in 1905.

1. Sir Charles Shuckburgh 2 Bt - Warwickshire 1698-1705

2. Sir George Shuckburgh-Evelyn 6 Bt - Warwickshire 1780-1804

Seats: Shuckburgh Hall (Park), Warwickshire (acq. early $13^{\text {th }}$ c., built c. 1500 , remod. c. 1600 , late $17^{\text {th }}$ c. and 1844, still there); Bourton Hall, Warwickshire (medieval, purch. c. 1590 , rebuilt late $18^{\text {th }}$ c., add. 1875-85, sold 1906, now offices); Buxted Place, Sussex (acq. by mar. 1797 from Medleys, passed to Jenkinsons 1814, see above)

Estates: Bateman 3502 (E) 6290

Title: Baronet 1660-

Notes: 6 Bt and four others in ODNB.

Medley

Origins: Founder a wine merchant in Portugal and subsequently country gentleman in Sussex mid-18 ${ }^{\text {th }}$ century. Suffered heavy losses in the Lisbon earthquake of 1755 . Sir George Shuckburgh-Evelyn 6 Bt married Julia, daughter and heiress of John Evelyn of Felbridge, Surrey and heiress in 1796 of her uncle George Medley MP.

1. George Medley - Seaford 1768-80 Esat Grinstead 1783-90

Seats: Buxted Place (Park), Sussex (purch. and built 1722, passed by mar. to Shuckburghs 1797 see above); Hever Castle, Kent

Estates: Wife of George Medley, née Waldo, inheritor of Hever Castle had passed Hever to a cousin - in Bateman 2798 (E) 3837. Rubinstein - Jane, widow of George Medley, left $£ 180,000$ in probate in 1829.

Notes: Waldos were probably London merchants.

\section{JENNINGS I}

Origins: Granted arms 1641. Kt 1660. High Sheriff 1675. The first MP was a government official and Mayor of Ripon.

1. Sir Edmund Jennings - Ripon $165916601673-791685$ 1690-91

2. Sir Jonathan Jennings - Ripon 1659 1689-95

3. Jonathan Jennings - Ripon 1691-1701

Notes: Residents of Ripon. 


\section{JENNINGS II}

Origins: In London in business in the $16^{\text {th }}$ century. Gentry by 1640. First MP 1640. Sir John Jennings MP was an admiral. Kt 1704.

1. Sir John Jennings - Queenborough 1705-10 Portsmouth 1710-11 Rochester 1715-34

2. Edward Jennings - East Looe 1713-15

3. Philip Jennings - Queenborough 1715-22

4. George Jennings - Whitchurch 1757-68 St. Germans 1768-74 Thetford 1784-90

5. Sir Philip Jennings-Clerke $1 \mathrm{Bt}-$ Totnes $1768-88$

Seats: Duddleston Hall, Shropshire; Newsells Park, Hertfordshire (built $17^{\text {th }}$ c., fire c. 1943, new house)

Title: Baronet 1774-88

Notes: $1 \mathrm{Bt}$ and one other in ODNB.

\section{JERVIS}

Earl St. Vincent (1797-1823 GB)

Origins: An old but impoverished family settled in Staffordshire by the $17^{\text {th }}$ century. A number were lawyers. The 1 Earl, son of a barrister and counsel to the Admiralty, was a celebrated admiral. On the death of the 1 Earl, the Viscountcy passed by special remainder to a nephew through the female line.

1. John Jervis 1 Earl St. Vincent - Launceston 1783-84 Great Yarmouth 1784-90 Chipping Wycombe 1790-94

Seats: Little Aston Hall, Staffordshire (built c 1730, purch. $19^{\text {th }}$ c., remod. 1857, sold c. 1900); Park Hall, Staffordshire (acq. by Parkers early $17^{\text {th }}$ c., built early-mid- $17^{\text {th }}$ c., fire 1791, rebuilt 1790s, passed to Jervis by mar. c. 1810, family departed 1890s, fire 1970); Norton Disney, Lincolnshire (medieval, rebuilt $18^{\text {th }}$ c., acq. by mar. mid-19 ${ }^{\text {th }}$ c., sold c. 1900); The Hall (Sutton Hall), Sutton-on-Derwent, Yorkshire (medieval, acq. by mar. 1857, sold 1948); Meaford Hall, Staffordshire (purch. and built later $17^{\text {th }}$ C., remod. $19^{\text {th }}$ c., sold 1943)

Estates: 12676 (E) 20963

Title: Viscount St. Vincent 1801- UK

Peers: 7 peers 1797-1945

1 in Cabinet 1801-04

Notes: 1 Earl in ODNB. 


\section{Цervis}

Origins: The senior line of the Jervis family of which the Earl was a cadet. First MP was a leading barrister, his son, also an MP, became Chief Justice of the Common Pleas 1850.

1. Thomas Jervis - Great Yarmouth 1802-06

2. Sir John Jervis - Chester 1832-50

3. Swynfen Jervis - Bridport 1837-41

4. John Jervis - Horsham 1847-48

Seats: Darlaston Hall, Staffordshire (late medieval, purch. 1685, sold 1880, demolished 1953); Chatcull Hall, Staffordshire (medieval, still owned later $19^{\text {th }} \mathrm{c}$.)

Notes: Two in ODNB.

JERVOISE [Clarke, Purefoy]

Jervoise

Origins: The grandfather of the first MP was a mercer and Alderman of London in the $16^{\text {th }}$ century. Purchased an estate 1538. First MP 1621. Another MP 1640.

1. Thomas Jervoise - Hampshire 1680-81 1689-90

2. Thomas Jervoise - Stockbridge 1691-95 Hampshire 1698-1702 Plympton 1702-03 Hindon 1704-05 Hampshire 1705-10

3. George Purefoy-Jervoise - Salisbury 1813-18 Hampshire 1820-26

Seats: Herriard House (Park), Hampshire (purch. 1538, rebuilt 1703-06, demolished 1965); The Moat (Moat House), Wiltshire (purch. 1542, built $17^{\text {th }}$ c., remod. 1766, remod. early $19^{\text {th }}$ c., still owned mid-19 ${ }^{\text {th }}$ c.)

Estates: Bateman 9846 (E) 10057

Notes: Herriard was acquired by the Cowdray family c. Edward III. An heiress married a younger son of Lord St. John (Paulet). A Paulet (see Powlett) heiress married 1601 Thomas Jervoise MP and carried the estates to that family. The Jervoise family succeeded 1762 by marriage to the Purefoy of Shalstone House, Buckinghamshire estates (first MP 1654). They eventually passed by the marriage in 1832 of a Jervoise heiress to Thomas Fitzgerald (in Bateman 5475 (E) 5586).

\section{Clarke-Jervoise}

Origins: On the death of Thomas Jervoise MP (1691-1710) (see above) of Herriard, Jervoise Clarke took the additional name Jervoise on inheriting the estates from his 
maternal grandfather. The Clarkes descended from Sir Samuel Clarke, a skinner and Lord Mayor of London, Kt 1712.

1. Jervoise Clarke-Jervoise - Yarmouth (IoW) 1768-69 1774-79 Hampshire 1779-90 Yarmouth 1791-1808

2. Thomas Clarke-Jervoise - Yarmouth 1787-90

3. Sir Jervoise Clarke-Jervoise $2 \mathrm{Bt}-\mathrm{S}$. Hampshire 1857-68

Seat: Idsworth Park, Hampshire (built mid-16 ${ }^{\text {th }}$ c., remod. $18^{\text {th }}$ c., purch. 1790, abandoned due to railway encroachment, new house on new site built 1852, add. 1912, sold 1974, flats)

Estates: Bateman 8932 (E) 5413

Titles: Baronet 1813-1933

JODRELL [Lombe]

Jodrell

Origins: Three generations of barristers led to the first MP. The Jodrells succeeded to the Lombe Baronetcy by special remainder through marriage to an heiress.

1. Paul Jodrell - Old Sarum 1751

2. Richard Paul Jodrell - Seaford 1790-92 1794-96

3. Henry Jodrell - Great Yarmouth 1796-1802 Bramber 1802-12

Seats: Bayfield Hall, Norfolk (medieval, rebuilt c. 1740, purch. 1766, passed to Cokes by mar. 1929); Salle Park, Norfolk (built 1761, acq. by mar. 1817, sold 1890); Duffield, Derbyshire (purch. and built early $18^{\text {th }} \mathrm{c}$., still resident early $19^{\text {th }} \mathrm{c}$., house leased or sold by mid-19 ${ }^{\text {th }} \mathrm{c}$.)

Estates: Bateman 5972 (E) 6735 and 2407 (E) 3081 and 13832 (E) 17789 (Evans-Lombe). 2 Bt left £250,000 plus land in 1861.

Title: Baronet 1784-1929

Notes: 2 Bt and two others in ODNB.

Lombe

Origins: The father of the first MP was born a Beevor who took the name Lombe on inheriting Great Melton in 1817 (probably an illegitimate son). The Lombes were textile manufacturers who introduced a new technique of silk throwing in the early $18^{\text {th }}$ century. The first mill was built in Derby in 1715 , which continued to operate until 1908. Kt 1727. The first Lombe Bt was formerly named Hase, and succeeded to the Lombe estates in 1762. 


\section{Edward Lombe - Arundel $1826-30$}

Seat: Great Melton Hall, Norfolk (built 1611, purch. 1713, abandoned 1899, derelict, became a ruin, still own estate); Bylaugh Hall, Norfolk (won by gambling from Lloyd famly 1794, built 1847-52, sold 1917, gutted 1952, restored c. 2000s, hotel)

Estates: Sir Thomas Lombe left £120,000 in 1739. Rubinstein - 1 Bt. left £160,000 in probate 1817. The rebuilding of Bylaugh c. 1850 may have cost $€ 38,000$. (Franklin, The Gentleman's Country House, 258)

Title: Baronet - see above

Notes: Three in ODNB.

\section{JOICEY}

\section{Baron Joicey (1906- UK)}

Origins: The father of the 1 Baron was a mining engineer who invested in coal mines 1828. 1 Baron was Chairman of the firm that managed the largest coalfield in Durham and also manufactured wire rope. They were also involved with the railways.

1. John Joicey - N. Durham $1880-81$

2. James Joicey 1 Baron Joicey - Chester-le-Street 1885-1905

Seats: Ford Castle, Northumberland (medieval, ruined and rebuilt by 1509, ruined c. 1648, remod.1694, rebuilt 1761-1800, rebuilt 1861-65, purch. 1907, remod. 1938, donated to local council for institutional use 1970s); Newton, Northumberland (resident second half $19^{\text {th }}$ c.); Longhirst Hall, Northumberland (purch. 1890s, still own)

Estates: Bateman 7854 (E) 7563. The 1 Baron left £1,500,000 in 1936. Owned 16,000 acres in 2015.

Title: Baronet 1893-

Peers: 3 peers 1906-45

Notes: 1 Baron in ODNB.

\section{JOLLIFFE}

\section{Baron Hylton (1866- UK)}

Origins: Robert de Hylton was summoned to Parliament as Baron Hylton in 1295, but the descent became confused. The de jure heirs, who did not use the titles, died out in 1746. Anne Hylton, the heiress to Hylton Castle, Durham married a Musgrave Baronet of Hayton Castle, Cumberland (see Musgrave). Her granddaughter, Eleanor Hylton married William Jolliffe. Eleanor's grandson was created Baron Hylton in 1866. (see Musgrave) 
1. John Jolliffe - Heytesbury $1660-79$

2. William Jolliffe - Poole 1698-1705

3. Sir William Jolliffe - Petersfield 1734-41

4. John Jolliffe - Petersfield 1741-54 1761-68

5. William Jolliffe - Petersfield 1768-1802

6. Thomas Jolliffe - Petersfield 1780-87

7. Hylton Jolliffe - Petersfield 1796 1802-34

8. William Jolliffe 1 Baron Hylton - Petersfield 1830-32 1837-38 1841-66

9. Gilbert Jolliffe - Petersfield 1830-31

10. Hedworth Jolliffe 2 Baron Hylton - Wells 1855-68

11. William Jolliffe - Petersfield 1874-80

12. Hylton Jolliffe 3 Baron Hylton - Wells Div. Somerset 1895-99

Seats: Ammerdown Park (House), Somerset (purch. and built 1788, add. 1855 and 1877, remod. 1901, still own); Merstham House, Surrey (purch. and built 1788, demolished c. 1834, new house built, sold 1899, demolished 1950s); Crofton Hall, Worcestershire (medieval, acq. by mar. 1633, fire 1645, rebuilt, passed out of the family by mar. 1758); Trotton Place, Sussex (purch. 1779, sold 1786); Botham Hall, Staffordshire (purch. c. 1600 , passed out of family by mar. 1712 , demolished early $19^{\text {th }}$ c.); Caverswall Castle, Staffordshire (built $13^{\text {th }}$ c., decayed $16^{\text {th }}$ c., new house c. 1615 , purch. 1655 , passed out of family by mar. 1712); Hayton Castle, Cumberland (built $15^{\text {th }}$ c., rebuilt 1609 , passed to Joliffes by mar. c. 1815, leased to farmers, sold 1903)

Estates: Bateman 10058 (E) 17072

Title: Baronet 1821-

Peers: 4 peers 1866-1945

Notes: John Hylton of Hylton Castle, Durham (medieval, extended c. 1700, burned 1856 , rebuilt $1863-69$, ruin $20^{\text {th }}$ c., engulfed by urban area), the last of the male line died in 1746. His niece married a Musgrave, and the Castle was sold 1758 to the Bowes family of Gibside (see Lyon). 1 Baron and one other in ODNB.

\section{JONES I IRELAND}

Origins: A Welsh family moved to Ireland 1606, bishop 1632 - acquired estates from 1622. Rose through the military, the law, office, marriage, and the Church. (Burtchaell, Genealogical Memoirs of the Members of Parliament for the County and City of Kilkenny, 63) Sheriff 1682. First \{MP 1639\}. Another \{MP 1656\}.

1. Sir Theophilus Jones - Meath 1660-61

2. Oliver Jones $-\{$ Knocktopher 1661-64\}

3. Nicholas Jones - \{Sligo 1692-93 County Leitrim 1695-99 1703-42\}

4. Theophilus Jones - \{County Leitrim 1761-68 Coleraine 1769-76 County Leitrim 1776-83 Monaghan 1783-90 County Leitrim 1790-1800\} 1801-02 
5. Walter Jones - \{Coleraine 1798-1800\} 1801-09

6. Theobald Jones - County Londonderry 1830-57

Seats: Headfort House, Leitrim (acq. late $17^{\text {th }}$ c., still resident in $20^{\text {th }}$ c.); Cork Abbey, Wicklow; Hayle Place, Kent (built mid-18 ${ }^{\text {th }}$ c., add. 1830); Bealanamore, Dublin; Bovagh House, Londonderry (built c. 1740 , resident first half $19^{\text {th }} \mathrm{c}$.)

Estates: Bateman 9904 (I) 4702. Worth £1,200 pa in 1713. Held 14,000 acres worth between $€ 5,000$ and $€ 9000$ pa in 1803.

Notes: The Jones estates were broken up among three heiresses in 1839. One married a younger son of the Earl of Romney (see Marsham), who succeeded to Headfort and took the name Jones. Five in ODNB.

JONES II WALES

Origins: The first MP was a lawyer of obscure origin. Became leading gentry in the late $17^{\text {th }}$ century. First MP 1654 for Breconshire.

1. Edward Jones - Breconshire 1685-87 1689-90 1695-96

2. Roger Jones - Brecon 1713-22

Seat: Buckland Hall, Breconshire (medieval, rebuilt early $17^{\text {th }}$ c., purch. 1709 , sold by heirs 1756)

Notes: Male line extinct 1741.

\section{JONES III ENGLAND \& WALES}

Origins: Prominent in Shrewsbury from the reign of Elizabeth I. First MP 1656 for Shrewsbury. Another MP 1659. The second MP was a barrister and then Lord Chief Justice.

1. Sir Thomas Jones - Shrewsbury $1660-76$

2. Thomas Jones - East Grinstead 1685-87

3. Thomas Jones - Shrewsbury 1710 1713-15

Seats: Cerreghwfa (Carreghofa, Carreghova), Montgomeryshire (medieval castle, acq. mid-1 $7^{\text {th }}$ c., resident $18^{\text {th }}$ c.); Caneghora, Denbighshire

\section{JONES-PARRY WALES}

Origins: The Joneses were seated at Llwyn Onn from the Middle Ages. Margaret Parry married in 1780 Thomas Jones of Llwyn Onn and the Parry estates passed to the Joneses. The first Parry was a Colonel under Cromwell and married an heiress. 
1. John Parry - Caernarvonshire 1780-90

2. Sir Love Jones-Parry - Horsham 1807-08 Caernarvonshire 1835-37

3. Sir Thomas Jones-Parry $1 \mathrm{Bt}$ - Caernarvonshire 1868-74 Caernarvon District 1882-86

Seats: Wernfawr (Wern Fawr), Caernarvonshire (Jones seat); Llwyn (Lwyn) Onn, Denbighshire (Jones seat from Middle Ages, sold 1910); Madryn Castle (Park), Caernarvonshire (acq. by Parrys by mar. 1708, passed to Jones family by mar. 1780, sold 1910)

Estates: Bateman 10025 (W) 5750 and 4699 (W) 2626

Title: Baronet 1886-91

Notes: One in ODNB.

\section{KAVANAGH IRELAND}

Origins: “The MacMorrough”. Kings of Leinster and High Kings of Ireland down to the reign of Henry VIII. Protestant by 1641. Remained one of the great Gaelic families of Ireland into the $20^{\text {th }}$ century. First $\{$ MP 1541\}. Two other $\{$ MPs 1613-34\}.

1. Bryan Kavanagh - \{Kilkenny 1796-97\}

2. Thomas Kavanagh - \{Kilkenny 1797-99\} County Carlow 1826-31 1835-37

3. Arthur Kavanagh - County Wexford 1866-68 County Carlow 1869-80

4. Walter Kavanagh - County Carlow 1908-10

Seats: Borris House, Carlow (acq. $13^{\text {th }}$ c.?, castle, rebuilt c. 1720-41, damaged 1798, rebuilt c. 1820, still own); Ballyraggert, Kilkenny

Estates: Bateman 29025 (I) 15608

1 Ld Lt $19^{\text {th }}$

Notes: Two in ODNB.

KAYE [Lister]

Origins: Acquired Woodsome (resident there since $14^{\text {th }}$ century) c. 1520 and added gradually to their estates through piecemeal accumulation of property over four generations between c. 1550-1662, moving from modest to greater gentry. They worked to increase their fortune both through the textile business and the iron industry. (Cliffe, The Yorkshire Gentry from the Reformation to the Civil War, 96-97) They also mined coal. The Kayes inherited the Lister estates by marriage in 1745. First MP 1610.

1. Sir John Kaye 2 Bt - Yorkshire 1685-87 1689-98 1701 1702-06

2. Sir Arthur Kaye $3 \mathrm{Bt}-$ Yorkshire 1710-26

3. Sir John Lister-Kaye 4 Bt - York 1734-41 